Int. J. Morphol.,

31(4):1227-1232, 2013.

\title{
Scopolamine Reduces the Density of M1 Muscarinic Neurons in Rats' Hippocampus
}

\author{
La Escopolamina Reduce la Densidad de las Neuronas \\ Muscarínicas M1 en el Hipocampo de Ratas
}

Jahanshahi, M."; Nickmahzar, E. G.**; Seif-hoseini, S. ${ }^{* *}$; Babakordi, F.** \& Moharreri, A.**

JAHANSHAHI, M.; NICKMAHZAR, E. G.; SEIF-HOSEINI, S.; BABAKORDI, F. \& MOHARRERI, A. Scopolamine reduces the density of M1 muscarinic neurons in rats' hippocampus. Int. J. Morphol., 31(4):1227-1232, 2013.

SUMMARY: Cholinergic system in CNS is involved in learning and memory. Scopolamine as muscarinic acetylcholine receptor antagonist is used for creation of memory impairment. The purpose of this study is evaluation of scopolamine-based amnesia on memory retention and the effect of this phenomenon on the number of neurons contains M1-receptors in the male Wistar rats hippocampal regions. Thirty-five male Wistar rats $(200 \pm 20 \mathrm{~g})$ were distributed randomly into five groups. Control group (intact samples) and 3 experimental groups with sham group (saline) were tested by the method of passive avoidance (shuttle box) in doses of $0.2,0.5$ and 1 $\mathrm{mg} / \mathrm{kg}$ (intraperitoneally) as a single dose. After one week, memory test was taken from the rats. Finally, brains dissected from sacrificed rats, and then processed tissues were stained with antibody against M1 receptors (Immunohistochemistry technique) followed by counting of hippocampal CA1, CA3 and DG regions. Our results showed significant decrease in neurons contains M1-receptors in all area of hippocampus. We found that the less number of M1-neurons showed in $1 \mathrm{mg} / \mathrm{kg}$ dose of scopolamine. We concluded that scopolamine as muscarinic acetylcholine receptor antagonist can reduce dose-dependently the density of M1-neurons in all areas of hippocampus.

KEY WORDS: M1 receptor; Scopolamine; Avoidance memory; Hippocampus; Rat.

\section{INTRODUCTION}

The hippocampus as the main part of limbic system is a key structure in the formation and retention of memory. Acetylcholine is one of several neuromodulators in the hippocampus and most of its known effects are mediated by the muscarinic family of receptors (M1 \pm M5). Cholinergic basal forebrain neurons in Alzheimer's disease Degenerated and it has been suggested to contribute to the dementia syndrome (Rouse et al., 2000).

We have two types of acetylcholine receptors, muscarinic and nicotinic (Chiba et al., 2010), and muscarinic acetylcholine receptors divided to five subtypes: M1, M2, M3, M4, M5 (Volpicelli \& Levey, 2004; Lebois et al., 2009). Although the role of each subtype is poorly known, in the hippocampus the muscarinic receptors are related to learning and memory (Ferreira et al., 2003).

In central and peripheral nervous system the muscarinic acetylcholine receptors (mAChRs) play critical functions in regulating the activity of many important functions
(Bymaster et al., 2003). The hippocampus and prefrontal cortex that important for cognition are expressed the highest levels of M1 and M2 receptors (Haley et al., 2011). In these regions amyloid plaques developed in Alzheimer's disease brains and this receptor subtype has long been assumed as a potential therapeutic target (Langmead et al., 2008).

Scopolamine known as hyoscine, a nonspecific muscarinic receptor antagonist, confers impairment of learning acquisition and short-term memory and reduces neuronal density in the rats' hippocampus (Seifhosseini et al., 2011). Some evidence indicate the between Alzheimer's disease patients and scopolamine treated animals is exist similarities in the memory deficit (Azami et al., 2010).

Therefore, the main question was whether scopolamine (muscarinic antagonist) is effective only on the function of receptors or it is effective on the number of neurons containing receptors. On the other hands, the aim of this study was to evaluate the effects of scopolamine (as muscarinic receptor

\footnotetext{
* Associate Professor of Anatomy, Neuroscience Research Center, Department of Anatomy, Golestan University of Medical Sciences, Gorgan, Iran.

*** Neuroscience Research Center, Golestan University of Medical Sciences, Gorgan, Iran.
} 
antagonist) on the density of neurons contain M1 receptor in male Wistar rats hippocampal formation.

\section{MATERIAL AND METHOD}

Animals. Thirty-five male Wistar rats (Pasteur Institute, Amol, Iran), weighting $200 \pm 20 \mathrm{~g}$ at the time of training, were used in passive avoidance task. They had free access to food and water, were housed seven in a cage, and kept at controlled temperature $\left(22 \pm 2^{\circ} \mathrm{C}\right)$ under a $12 / 12 \mathrm{~h}$ light-dark cycle (light beginning at 07:00 h) at least 1 week before the beginning of the experiments.

The rats were randomly distributed into five groups $(\mathrm{n}=7)$ as follows:

1. Control: Without receiving scopolamine and behavioral test.

2. Saline-control: received saline + behavioral test.

3. Exp. $0.2 \mathrm{mg} / \mathrm{kg}$ : received scopolamine $(0.2 \mathrm{mg} / \mathrm{kg} \mathrm{IP})+$ behavioral test.

4. Exp. $0.5 \mathrm{mg} / \mathrm{kg}$ : received scopolamine $(0.5 \mathrm{mg} / \mathrm{kg} \mathrm{IP})+$ behavioral test.

5. Exp. $1 \mathrm{mg} / \mathrm{kg}$ : received scopolamine $(1 \mathrm{mg} / \mathrm{kg} \mathrm{IP})+$ behavioral test.

All experiments were carried out during the light phase between 09:00 and 15:00 h. Experimental groups consisted of 7 animals and each animal was tasted once only. All procedures were performed in accordance with institutional guidelines for animal care and use.

Drugs. Scopolamine hydrobromide (Tocris, Bristol, UK) was dissolved in saline $(\mathrm{NaCl} 0.9 \%)$ at final concentrations of $0.2,0.5$ and $1 \mathrm{mg} / \mathrm{kg}$, and was injected intraperitoneally one day after the training.

Inhibitory Avoidance Procedures. Our previous studies (Azami et al.; Seifhosseini et al.) described passive avoidance as follows: each animal was gently placed in the brightly lit compartment of the apparatus; after $5 \mathrm{~s}$ the guillotine door was opened and the animal was allowed to enter the dark module. The latency with which the animal entered the dark chamber was recorded. Animals that waited more than $120 \mathrm{~s}$ to enter the dark chamber were excluded from the experiments. Once the animal entered with all fourpaws to the next chamber, the guillotine door was closed and the rat was immediately withdrawn from the compartment. This trial was repeated after $30 \mathrm{~min}$. As in the acquisition trial, after $5 \mathrm{~s}$ the guillotine door was opened, and as soon as the animal entered the dark (shock) compartment the door was closed; and a foot shock $(50 \mathrm{~Hz}$, $1 \mathrm{~mA}$ and $3 \mathrm{~s}$ ) was immediately delivered to the grid floor of the dark room. After $20 \mathrm{~s}$, the rat was removed from the apparatus and placed temporarily into its home cage.

The animal was retested two minutes later, in the same way as in the previous trials; if the rat did not enter the dark compartment during $120 \mathrm{~s}$, a successful acquisition of inhibitory avoidance response was recorded. Otherwise, when the rat entered the dark compartment (before $120 \mathrm{~s}$ ) a second time, the door was closed and the animal received the shock again. After retesting, if the rat learned inhibitory avoidance response successfully, it was moved to the cage and $24 \mathrm{~h}$ after the training, received scopolamine or saline (i.p.). On the test day (one week after training) each animal gently placed in the light compartment and after $5 \mathrm{~s}$ the door was opened, and step through latency (sec) was recorded in the absence of electric foot shocks, as indicator of inhibitory avoidance behavior.

Histology. Animals were deeply anesthetized with chloroform, decapitated and the brains removed from the skull and remained in paraformaldehyde (4\%) for two weeks, and then, the brains transfer to tissue processor apparatus. Following this session, samples of the brain were embedded in paraffin and kept in refrigerator. Then the brains were sliced at a thickness of $8 \mathrm{~mm}$ in the coronal plane (from Bregma $-2.5 \mathrm{~mm}$ to $-4.5 \mathrm{~mm}$ of the hippocampal formation) (Paxinos \& Watson, 1998) with a rotary microtome (MK 1110).

Immunohistochemistry. At first samples incubated (30 min) at $37^{\circ} \mathrm{C}$, then, for deparaffinization and hydrate procedures embedded in xylene and different degrees of ethanol. After these the samples washed in purified water. Following this stage the sections were embedded in epitope retrieval for 20 min, at $90^{\circ} \mathrm{C}$ (IHC World, USA). After this the samples remained in room temperature for $20 \mathrm{~min}$.

For buffered washing the samples were washed two times in PBS/Tween 20 (IHC World, USA). Following block step carried out with proxidase blocking solution $(3 \% \mathrm{H} 2 \mathrm{O} 2$ in PBS) (10 min, at room temperature). After the blocking, sections were washed two times in PBS/Tween20. The sections were blocked with Avidin/Biotin Blocking Solution (IHC World, USA) (for $30 \mathrm{~min}$ at room temperature), polyclonal primary antibody (M9808, Sigma-Aldrich) was applied at 1:200 dilution and the sections were incubated for $1 \mathrm{~h}$ at $37^{\circ} \mathrm{C}$. after this stage the sections washed one time in PBS/Tween20 (10 min), then incubated in biotinylated goat anti rabbit $\operatorname{IgG}$ (abcam) for $1 \mathrm{~h}$ at $37^{\circ} \mathrm{C}$, then, Streptavidin protein (HRP, abcam) diluted 1:5000 (30 min, room temperature), and washed in PBS/Tween 20 (10 min), 
and visualized with DAB. Finally, the sections were dehydrated in ethanol, cleared in xylene and cover slipped with entellan (Fig. 1).

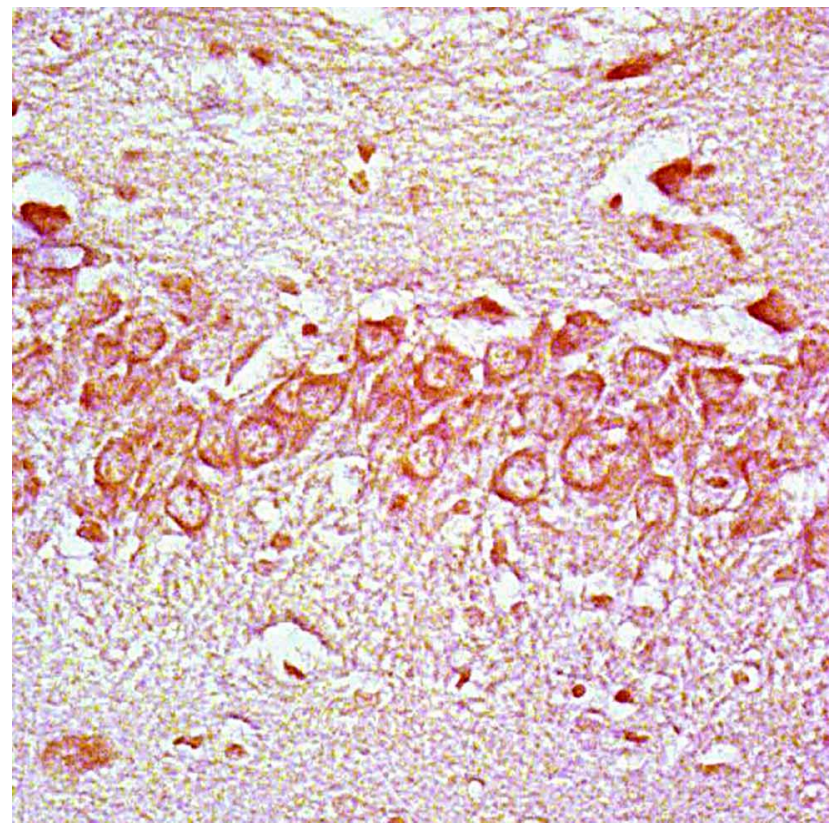

Fig. 1. Micrograph of CA3 area of hippocampus with AntiM1 immunohistochemistry staining. Neurons contain M1 receptor in their membrane showed brown.

Stained slides were visualized using a system composed of a binocular microscope, Equipped with a digital video camera connected to a video monitor. Using OLYSIA Autobioreport software, Olympus Co, the appropriate grids were superimposed on the pictures and the cells were counted manually in $30000 \mathrm{~mm} 2$. To perform an unbiased measurement, the individual was double-blinded and only the cells with significant M1 cell characteristics were counted (Jahanshahi et al., 2006; Jahanshahi et al., 2011).

Statistical Analysis. Comparisons between groups were made with one-way analysis of variance (ANOVA). Posthoc comparison of means was carried out with the Tukey test for multiple comparisons, when appropriate. A difference with $\mathrm{p} \leq 0.05$ between the experimental groups was considered statistically significant.

\section{RESULTS}

The latency of response in the sham group was $128.57 \pm 97.48 \mathrm{~s}$, while for the experimental groups it was a much shorter time $(0.2 \mathrm{mg} / \mathrm{kg}=52.86 \pm 9.51 \mathrm{~s}, 0.5 \mathrm{mg} / \mathrm{kg}=$ $50.86 \pm 57.32 \mathrm{~s}$ and $1 \mathrm{mg} / \mathrm{kg}=26.57 \pm 34.07 .48 \mathrm{~s})$. Data showed a significant difference between sham and experimental groups $(\mathrm{p}<0.05)$. We found no significant difference between the experimental groups with the other.

Table I. Mean and SD of muscarinic (M1) cells number in CA1 area of Hippocampus.

\begin{tabular}{lccc}
\hline P value & Std. Deviation & Mean & Groups - CA1 \\
\hline & 8.021 & 38.25 & Control \\
0.769 & 15.412 & 41.94 & Sham-Saline \\
0.001 & 6.557 & 25.06 & Scopolamine 0.2 \\
0.000 & 6.329 & 22.06 & Scopolamine 0.5 \\
0.000 & 3.623 & 14.06 & Scopolamine 1 \\
\hline
\end{tabular}

As we showed in Table I, scopolamine decreased the number of M1 cells in CA1 area of hippocampus ( $\mathrm{p}<0.001)$. This decrease was dose-dependent. The less number of neurons contains M1 receptors showed in $1 \mathrm{mg} / \mathrm{kg}$ dose of scopolamine $(14.06 \pm 3.62)$. There is no difference statistically between control and sham groups.

In Table II we showed the Mean and SD of neurons contains M1 number in CA3 area of hippocampus. The less number of neurons contains $\mathrm{M} 1$ receptors showed in $1 \mathrm{mg} /$ $\mathrm{kg}$ dose of scopolamine (13.44 \pm 4.08$)$. The differences were significant statistically in all doses $(\mathrm{p}<0.001)$.

Table II. Mean and SD of muscarinic (M1) cells number in CA3 area of Hippocampus.

\begin{tabular}{lccc}
\hline P value & Std. Deviation & Mean & Groups - CA3 \\
\hline & 7.641 & 34.88 & Control \\
0.855 & 9.562 & 37.31 & Sham-Saline \\
0.000 & 7.125 & 20.31 & Scopolamine 0.2 \\
0.000 & 4.542 & 14.69 & Scopolamine 0.5 \\
0.000 & 4.082 & 13.44 & Scopolamine 1 \\
\hline
\end{tabular}

In dentate gyrus (Table III), the less number of neurons contains M1 receptors showed in $1 \mathrm{mg} / \mathrm{kg}$ dose of scopolamine (13.81 \pm 4.19$)$.

Table III. Mean and SD of muscarinic (M1) cells number in DG area of Hippocampus.

\begin{tabular}{lccc}
\hline P value & Std. Deviation & Mean & Groups - DG \\
\hline & 11.387 & 49.94 & Control \\
0.986 & 21.312 & 52.25 & Sham-Saline \\
0.000 & 11.964 & 21.94 & Scopolamine 0.2 \\
0.000 & 7.971 & 19.75 & Scopolamine 0.5 \\
0.000 & 4.199 & 13.81 & Scopolamine 1 \\
\hline
\end{tabular}




\section{DISCUSSION}

This study was conducted to evaluate that effect of scopolamine-based amnesia on the density of M1muscarinic neurons with immunohistochemistry technique. We found that scopolamine in all areas of hippocampus reduced the number of neurons contain the M1 receptor dose dependently. Unfortunately we could not recognize only the number of M1 receptors with this method.

The most highly expressed muscarinic receptor in the prefrontal cortex and hippocampus is the type 1 (M1) (Fredrickson et al., 2008; Nathanson, 2008). Some previous studies indicate the role of muscarinic receptors to avoidance memory, for example, Power and co-workers demonstrated that both M1 and M2 pharmacological receptor subtypes were important for memory consolidation of inhibitory avoidance (Power et al., 2003). As we show, Injection of scopolamine as a muscarinic antagonist intrahippocampal (Azami et al.) or intra-peritoneal (Kwon et al., 2009; Seifhosseini et al.) impairs the avoidance memory. The other antagonist, pirenzepine, injected bilaterally into the dorsal hippocampus, significantly increased the number of errors in working memory (Ohno et al., 1994).

Other reports indicate an age-related decrease in M1 receptor (Wagster et al., 1990; Vannucchi \& GoldmanRakic, 1991). Also Tayebati found age-related M1 receptor reduce density in pyramidal neurons of CA1 area of hippocampus, also M1 receptor density in the radial layer of CA3 area and in granular layer of the dentate gyrus in the old rats hippocampus have been observed (Tayebati et al., 2002).
Some studies have shown that in Alzheimer's disease the immunoreactivity decreased in M1 receptor (Flynn et al., 1995; Shiozaki et al., 2001). The other researches showed that in patients with Alzheimer's disease, M1 receptor agonists are proposed to increase cognitive function and neurogenesis (Fisher, 2008; Ma et al., 2009).

Araujo et al. (2011) showed that injection of scopolamine (15 mg/kg; SC) to dogs, reduces significantly the density of muscarinic receptor in older dogs in the frontal, parietal, and entorhinal segments. In this research similar to our study the reduction of muscarinic neurons was found.

\section{CONCLUSION}

It seems changes in the number of $\mathrm{M} 1$ receptors occur in some phenomenon such as aging and Alzheimer's disease. Therefore, we concluded that scopolamine as muscarinic acetylcholine receptor antagonist impairs the avoidance memory and it can reduce dose-dependently the density of M1-neurons in hippocampus.

\section{ACKNOWLEDGMENTS}

The authors would like to thank of the Neuroscience Research Center for behavioral and histological experiments. We are also thankful for financial support of research affair of Golestan University of Medical Sciences.

JAHANSHAHI, M.; NICKMAHZAR, E. G.; SEIF-HOSEINI, S.; BABAKORDI, F. \& MOHARRERI, A. La escopolamina reduce la densidad de las neuronas muscarínicas M1 en el hipocampo de ratas. Int. J. Morphol., 31(4):1227-1232, 2013.

RESUMEN: El sistema colinérgico en el SNC está implicado en el aprendizaje y la memoria. La escopolamina como receptor antagonista de acetilcolina muscarínico es utilizada para la creación del deterioro de la memoria. El propósito de este estudio es la evaluación de la amnesia basada en escopolamina sobre la retención de memoria y el efecto de este fenómeno en la cantidad de neuronas en receptores M1 en regiones del hipocampo en ratas macho Wistar. Se distribuyeron al azar, 35 ratas macho Wistar (200 \pm 20 g) en cinco grupos. El grupo de control (muestras intactas) y 3 grupos experimentales con grupo de tratamiento simulado (solución salina) analizadas por método de evasión pasiva (caja de transporte) en dosis de 0,$2 ; 0,5$ y $1 \mathrm{mg} / \mathrm{kg}$ (por vía intraperitoneal) como dosis única. Al término de una semana se realizó prueba de memoria de las ratas. Por último, los cerebros diseccionados de las ratas sacrificadas y los tejidos procesados fueron teñidos con anticuerpos contra los receptores M1 (técnica inmunohistoquímica), seguido por el recuento de regiones CA1, CA3 y DG del hipocampo. Nuestros resultados mostraron una disminución significativa en las neuronas con receptores M1 en toda el área del hipocampo. Se encontró que el número menor de neuronas M1, y fue demostrado en $1 \mathrm{mg} / \mathrm{kg}$ de dosis de escopolamina. Llegamos a la conclusión de que la escopolamina como antagonista del receptor de acetilcolina muscarínico puede, dependiendo de la dosis, reducir la densidad de neuronas M1 en todas las áreas del hipocampo.

PALABRAS CLAVE: Receptor M1; Escopolamina; Evasión de memoria; Hipocampo; Rata. 


\section{REFERENCES}

Araujo, J. A.; Nobrega, J. N.; Raymond, R. \& Milgram, N. W. Aged dogs demonstrate both increased sensitivity to scopolamine impairment and decreased muscarinic receptor density. Pharmacol. Biochem. Behav., 98(2):203-9, 2011.

Azami, N. S.; Piri, M.; Oryan, S.; Jahanshahi, M.; Babapour, V. \& Zarrindast, M. R. Involvement of dorsal hippocampal alphaadrenergic receptors in the effect of scopolamine on memory retrieval in inhibitory avoidance task. Neurobiol. Learn Mem., 93(4):455-62, 2010.

Bymaster, F. P.; McKinzie, D. L.; Felder, C. C. \& Wess, J. Use of M1-M5 muscarinic receptor knockout mice as novel tools to delineate the physiological roles of the muscarinic cholinergic system. Neurochem. Res., 28(3-4):437-42, 2003.

Chiba, T.; Yamada, M.; Torii, K.; Suzuki, M.; Sasabe, J.; Ito, M.; Terashita, K. \& Aiso, S. Effects of extracts from Cordyceps sinensis on M1 muscarinic acetylcholine receptor in vitro and in vivo. J. Receptor Ligand Channel Res., 3:97-104, 2010.

Ferreira, A. R.; Fürstenau, L.; Blanco, C.; Kornisiuk, E.; Sánchez, G.; Daroit, D.; Castro e Silva, M.; Cerveñansky, C.; Jerusalinsky, D. \& Quillfeldt, J. A. Role of hippocampal M1 and M4 muscarinic receptor subtypes in memory consolidation in the rat. Pharmacol. Biochem. Behav., 74(2):411-5, 2003.

Fisher, A. Cholinergic treatments with emphasis on $\mathrm{m} 1$ muscarinic agonists as potential disease-modifying agents for Alzheimer's disease. Neurotherapeutics, 5(3):433-42, 2008.

Flynn, D. D.; Ferrari-DiLeo, G.; Mash, D. C. \& Levey, A. I. Differential regulation of molecular subtypes of muscarinic receptors in Alzheimer's disease. J. Neurochem., 64(4):188891, 1995

Fredrickson, A.; Snyder, P. J.; Cromer, J.; Thomas, E.; Lewis, M. $\&$ Maruff, P. The use of effect sizes to characterize the nature of cognitive change in psychopharmacological studies: an example with scopolamine. Hum. Psychopharmacol., 23(5):425-36, 2008.

Haley, G. E.; Kroenke, C.; Schwartz, D.; Kohama, S. G.; Urbanski, H. F. \& Raber, J. Hippocampal M1 receptor function associated with spatial learning and memory in aged female rhesus macaques. Age (Dordr.), 33(3):309-20, 2011.

Jahanshahi, M.; Khoshbin Khoshnazar, A.; Azami, N. S. \& Heidari, M. Radiation-induced lowered neurogenesis associated with shortened latency of inhibitory avoidance memory response. Folia Neuropathol., 49(2):103-8, 2011.

Jahanshahi, M.; Sadegi, Y. \& Hosseini, A. Estimation of astrocyte number in different subfield of rat hippocampus. Pakistan $J$. Biol. Sci., 9(8):1595-7, 2006.
Kwon, S. H.; Kim, H. C.; Lee, S. Y. \& Jang, C. G. Loganin improves learning and memory impairments induced by scopolamine in mice. Eur. J. Pharmacol., 619(1-3):44-9, 2009.

Langmead, C. J.; Watson, J. \& Reavill, C. Muscarinic acetylcholine receptors as CNS drug targets. Pharmacol. Ther., 117(2):23243, 2008.

Lebois, E. P.; Bridges, T. M.; Lewis, L. M.; Dawson, E. S.; Kane, A. S.; Xiang, Z.; Jadhav, S. B.; Yin, H.; Kennedy, J. P.; Meiler, J.; Niswender, C. M.; Jones, C. K.; Conn, P. J.; Weaver, C. D., Lindsley CW. Discovery and characterization of novel subtypeselective allosteric agonists for the investigation of $\mathrm{M}(1)$ receptor function in the central nervous system. ACS Chem. Neurosci., 1(2):104-121, 2010.

Ma, L.; Seager, M. A.; Wittmann, M.; Jacobson, M.; Bickel, D.; Burno, M.; Jones, K.; Graufelds, V. K.; Xu, G.; Pearson, M.; McCampbell, A.; Gaspar, R.; Shughrue, P.; Danziger, A.; Regan, C.; Flick, R.; Pascarella, D.; Garson, S.; Doran, S.; Kreatsoulas, C.; Veng, L.; Lindsley, C. W.; Shipe, W.; Kuduk, S.; Sur, C.; Kinney, G.; Seabrook, G. R. \& Ray, W. J. Selective activation of the M1 muscarinic acetylcholine receptor achieved by allosteric potentiation. Proc. Natl. Acad. Sci. US A, 106(37):15950-5, 2009.

Nathanson, N. M. Synthesis, trafficking, and localization of muscarinic acetylcholine receptors. Pharmacol. Ther., 119(1):33-43, 2008.

Ohno, M.; Yamamoto, T. \& Watanabe, S. Blockade of hippocampal M1 muscarinic receptors impairs working memory performance of rats. Brain Res., 650(2):260-6, 1994.

Paxinos, G. \& Watson, C. The rat brain in stereotaxic coordinates. San Diego, Academic Press, 1998.

Power, A. E.; McIntyre, C. K.; Litmanovich, A. \& McGaugh, J. L. Cholinergic modulation of memory in the basolateral amygdala involves activation of both $\mathrm{m} 1$ and $\mathrm{m} 2$ receptors. Behav. Pharmacol., 14(3):207-13, 2003.

Rouse, S. T.; Edmunds, S. M.; Yi, H.; Gilmor, M. L. \& Levey, A. I. Localization of $\mathrm{M}(2)$ muscarinic acetylcholine receptor protein in cholinergic and non-cholinergic terminals in rat hippocampus. Neurosci. Lett., 284(3):182-6, 2000.

Seifhosseini, S.; Jahanshahi M.; Moghimi, A. \& Aazami, N. The Effect of Scopolamine on Avoidance Memory and Hippocampal Neurons in Male Wistar Rats. Basic Clin. Neurosci., 3(1):9-15, 2011.

Shiozaki, K.; Iseki, E.; Hino, H. \& Kosaka, K. Distribution of m1 muscarinic acetylcholine receptors in the hippocampus of patients with Alzheimer's disease and dementia with Lewy 
JAHANSHAHI, M.; NICKMAHZAR, E. G.; SEIF-HOSEINI, S.; BABAKORDI, F. \& MOHARRERI, A. Scopolamine reduces the density of M1 muscarinic neurons in rats' hippocampus. Int. J. Morphol., 31(4):1227-1232, 2013.

bodies-an immunohistochemical study. J. Neurol. Sci., 193(1):23-8, 2001.

Tayebati, S. K.; Amenta, F.; El-Assouad, D. \& Zaccheo, D. Muscarinic cholinergic receptor subtypes in the hippocampus of aged rats. Mech. Ageing Dev., 123(5):521-8, 2002.

Vannucchi, M. G. \& Goldman-Rakic, P. S. Age-dependent decrease in the affinity of muscarinic M1 receptors in neocortex of rhesus monkeys. Proc. Natl. Acad. Sci. U S A, 88(24):11475-9, 1991.

Volpicelli, L. A. \& Levey, A. I. Muscarinic acetylcholine receptor subtypes in cerebral cortex and hippocampus. Prog. Brain Res., 145:59-66, 2004.

Wagster, M. V.; Whitehouse, P. J.; Walker, L. C.; Kellar, K. J. \& Price, D. L. Laminar organization and age-related loss of cholinergic receptors in temporal neocortex of rhesus monkey. J. Neurosci., 10(9):2879-85, 1990.

\section{Correspondence to: \\ Dr. Mehrdad Jahanshahi \\ Department of Anatomy}

Neuroscience Research Center, Faculty of Medicine

Golestan University of medical Sciences

Km 4 Gorgan-Sari road (Shastcola)

Gorgan

IRAN

Tel: 0098-171-4420515

Fax: 0098-171-4420515

Email: mejahanshahi@yahoo.com

Received: 14-05-2013

Accepted: 09-09-2013 